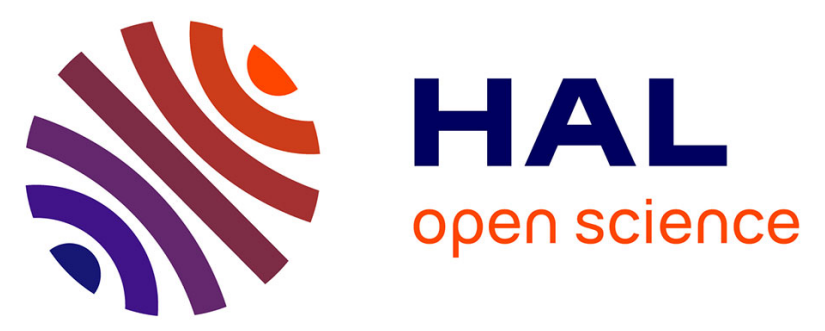

\title{
The Peptidic GHS-R Antagonist [D-Lys]GHRP-6 Markedly Improves Adiposity and Related Metabolic Abnormalities in a Mouse Model of Postmenopausal Obesity
}

L. Maletínská, R. Matyšková, J. Maixnerová, D. Sýkora, M. Pýchová, A. Špolcová, M. Blechová, J. Drápalová, Z. Lacinová, M. Haluzík, et al.

\section{To cite this version:}

L. Maletínská, R. Matyšková, J. Maixnerová, D. Sýkora, M. Pýchová, et al.. The Peptidic GHS-R Antagonist [D-Lys]GHRP-6 Markedly Improves Adiposity and Related Metabolic Abnormalities in a Mouse Model of Postmenopausal Obesity. Molecular and Cellular Endocrinology, 2011, 343 (1-2), pp.55. 10.1016/j.mce.2011.06.006 . hal-00723608

\author{
HAL Id: hal-00723608 \\ https://hal.science/hal-00723608
}

Submitted on 11 Aug 2012

HAL is a multi-disciplinary open access archive for the deposit and dissemination of scientific research documents, whether they are published or not. The documents may come from teaching and research institutions in France or abroad, or from public or private research centers.
L'archive ouverte pluridisciplinaire HAL, est destinée au dépôt et à la diffusion de documents scientifiques de niveau recherche, publiés ou non, émanant des établissements d'enseignement et de recherche français ou étrangers, des laboratoires publics ou privés. 


\section{Accepted Manuscript}

The Peptidic GHS-R Antagonist [D-Lys ${ }^{3}$ GHRP-6 Markedly Improves Adiposity and Related Metabolic Abnormalities in a Mouse Model of Postmenopausal Obesity

L. Maletínská, R. Matyšková, J. Maixnerová, D. Sýkora, M. Pýchová, A. Špolcová, M. Blechová, J. Drápalová, Z. Lacinová, M. Haluzík, B. Železná

PII: S0303-7207(11)00314-5

DOI: 10.1016/j.mce.2011.06.006

Reference: MCE 7890

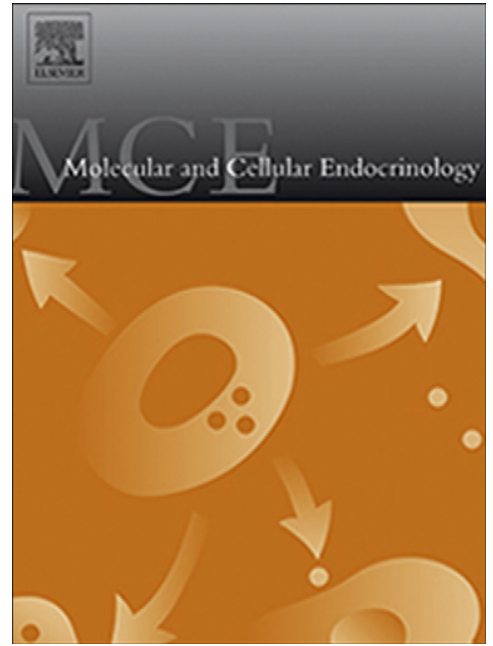

To appear in: Molecular and Cellular Endocrinology Molecular
and Cellular Endocrinology

Received Date: 12 April 2011

Revised Date:

9 June 2011

Accepted Date:

9 June 2011

Please cite this article as: Maletínská, L., Matyšková, R., Maixnerová, J., Sýkora, D., Pýchová, M., Špolcová, A., Blechová, M., Drápalová, J., Lacinová, Z., Haluzík, M., Železná, B., The Peptidic GHS-R Antagonist [DLys ${ }^{3}$ ]GHRP-6 Markedly Improves Adiposity and Related Metabolic Abnormalities in a Mouse Model of Postmenopausal Obesity, Molecular and Cellular Endocrinology Molecular and Cellular Endocrinology (2011), doi: 10.1016/j.mce.2011.06.006

This is a PDF file of an unedited manuscript that has been accepted for publication. As a service to our customers we are providing this early version of the manuscript. The manuscript will undergo copyediting, typesetting, and review of the resulting proof before it is published in its final form. Please note that during the production process errors may be discovered which could affect the content, and all legal disclaimers that apply to the journal pertain. 
The Peptidic GHS-R Antagonist [D-Lys ${ }^{3}$ GHRP-6 Markedly Improves Adiposity and Related Metabolic Abnormalities in a Mouse Model of Postmenopausal Obesity

L. Maletínskáa ${ }^{\text {, R. Matyškováa }}$, J. Maixnerováa ${ }^{a}$ D. Sýkora ${ }^{b}$, M. Pýchováa ${ }^{a}$ A. Špolcováa ${ }^{2}$ M. Blechováa ${ }^{a}$ J. Drápalovác, Z. Lacinovác, M. Haluzík ${ }^{\complement}$ and B. Železnáa ${ }^{a}$ Institute of Organic Chemistry and Biochemistry, ${ }^{b}$ Institute of Chemical Technology, and ${ }^{c}$ Third Department of Medicine, First Faculty of Medicine, Charles University, Prague, Czech Republic

Corresponding author:

Dr. Lenka Maletínská

Institute of Organic Chemistry and Biochemistry

Flemingovo n. 2

16610 Prague 6

Czech Republic

Tel. +420220183525

Fax +420220183571

e-mail: maletin@uochb.cas.cz

Key words: GHS-R, [D-Lys ${ }^{3}$ GHRP-6, [D-Arg ${ }^{1}$, D-Phe ${ }^{5}$, D-Trp ${ }^{7,9}$, Leu ${ }^{11}$ ]sub P, ovariectomized obese mice, metabolic syndrome, FGF21 
Abbreviations:

BAT brown adipose tissue

DIO diet-induced obesity

E2 17ß-estradiol-3-benzoate

FGF21 fibroblast growth factor 21

GHS-R ghrelin receptor

HF high fat (diet)

OVX ovariectomized

PPAR alpha peroxisome proliferator-activated receptor alpha

SC subcutaneous

SPa $\quad\left[D-\operatorname{Arg}^{1}\right.$, D-Phe ${ }^{5}$, D-Trp ${ }^{7,9}$, Leu $^{11}$ ]substance P

St standard (diet)

UCP1 uncoupling protein 1 


\section{Abstract}

It was demonstrated that estrogen deficiency and consuming high fat (HF) diet enhanced orexigenic activity of ghrelin. Therefore, we hypothesized that antagonizing of ghrelin action would attenuate food intake and body weight in mice obese both from ovariectomy (OVX) and feeding a HF diet.

Ghrelin receptor antagonist [D-Lys ${ }^{3}$ GHRP-6 after seven days of subcutaneous treatment markedly decreased food intake in OVX mice fed both HF and standard diets; furthermore, it reduced body weight and blood glucose, insulin and leptin, and increased $\beta$-hydroxybutyrate level and uncoupling-protein-1 mRNA in brown adipose tissue. Pairfeeding revealed that effect of $\left[D-L_{y s}{ }^{3}\right]$ GHRP-6 was primary anorexigenic. Estrogen supplementation reduced anorexigenic effects of [D-Lys $\left.{ }^{3}\right]$ GHRP-6. OVX [D-Lys $\left.{ }^{3}\right]$ GHRP6 treatment in mice on HF diet resulted in markedly increased circulating level and liver expression of a major metabolic regulator, fibroblast growth factor 21 .

Our data suggest that ghrelin antagonists could be especially beneficial in individuals with common obesity combined with estrogen deficiency. 


\section{Introduction}

Menopause and ovariectomy are often accompanied by increases in body weight due to a lack of the effects of sex hormones. Estrogen deficiency typically predisposes to the accumulation of visceral, rather than subcutaneous fat. An increase in body weight can be further potentiated by consumption of a high-energy, usually high-fat (HF) diet (Brown and Clegg, 2010; Shi and Clegg, 2009; Tena-Sempere, 2007). Similar to humans, ovariectomized (OVX) rodents fed HF diets develop obesity due to the lack of estrogen and the excess of consumed fat, and thus, these animals can serve as a model for commonly observed postmenopausal human obesity. In a previous study by our group, OVX mice fed HF diet were extremely prone to diet-induced obesity (DIO), which resulted in hyperleptinemia, hyperinsulinemia, hyperglycemia, and resistance to centrally administered leptin. Estrogen supplementation normalized central resistance to exogenous leptin and reduced the fat/body weight ratio and leptin and glucose levels (Matyšková et al., 2010).

Recently, OVX rats were shown to have increased circulating levels of the orexigenic gut peptide ghrelin, which positively correlated with transient hyperphagia and resulted in permanent weight gain. This orexigenic action of ghrelin in OVX rats was decreased by estrogen replacement (Clegg et al., 2007). The pivotal role of ghrelin in OVX-related weight gain was further supported by the finding that ghrelin receptor (GHS-R, growth hormone secretagogue receptor)-null mice were resistant to OVX-induced increases in food intake and body weight (Clegg et al., 2007). An important role of ghrelin in body weight regulation was previously documented based on the phenotype of both ghrelinand ghrelin-receptor null, i.e., Ghrl-/- and Ghsr-/-, mice who did not develop DIO when fed an HF diet from an early age (Wortley et al., 2005; Zigman et al., 2005). 
On the contrary, chronic ghrelin treatment in lean male mice decreased the expression of uncoupling protein 1 (UCP1) in brown adipose tissue (Tsubone et al., 2005) which points to a possible reduction of energy expenditure.

Inhibition of ghrelin action thus represents a promising approach for the treatment of obesity. Numerous non-peptide peptidomimetic ghrelin antagonists and inverse agonists have been developed and tested as promising anti-obesity agents (Asakawa et al., 2003; Castañeda et al., 2010; Chollet et al., 2009; Esler et al., 2007; Moulin et al., 2007; Nogueiras et al., 2006). Most of these substances are based either on the first synthetic peptidic ghrelin antagonist [D-Lys ${ }^{3}$ ]GHRP-6 (His-DTrp-DLys-Trp-DPhe-Lys$\mathrm{NH}_{2}$ ) (Smith et al., 1993) or ghrelin inverse agonists SPa ([D-Arg ${ }^{1}, \mathrm{D}-\mathrm{Phe}^{5}, \mathrm{D}-\mathrm{Trp}^{7,9}$, Leu ${ }^{11}$ substance P) (Cheng et al., 1997).

We hypothesized that ovariectomized mice with diet-induced obesity might be particularly sensitive to the inhibition of ghrelin action. Thus, we tested the effects of seven days of $\left[\mathrm{DLys}^{3}\right]$ GHRP- 6 or SPa administration on food intake, body fat content and metabolic and hormonal parameters in obese OVX female mice on an HF diet.

\section{Materials and Methods}

\subsection{Synthesis of GHS-R1a antagonists}

Peptides D-Lys ${ }^{3}$ ]GHRP-6 (His-DTrp-DLys-Trp-DPhe-Lys-NH ${ }_{2}$ ) and SPa ( [D-Arg ${ }^{1}$, DPhe $^{5}$, D-Trp ${ }^{7,9}$, Leu ${ }^{11}$ substance P, DArg-Pro-Lys-Pro-DPhe-Gln-DTrp-Phe-DTrp-LeuLeu-NH $\mathrm{N}_{2}$ ) were assembled in a solid-phase ABI433A synthesizer (Applied Biosystems, Foster City, CA, USA) by stepwise coupling of the corresponding Fmoc-amino acids to the growing chain on Rink amide resin (1\% DVB, 200-400 mesh, $0.65 \mathrm{mmol} / \mathrm{g}$, IRIS,

Biotech $\mathrm{GmbH}$, Marktredwitz, Germany). Fully protected peptide resins were 
synthesized, and peptides were purified and analyzed according to a standard procedure (Maixnerová et al., 2007).

\subsection{Experimental animals}

All experiments followed the ethical guidelines for animal experiments and the Czech Republic law No. 246/1992 and were approved by the Committee for experiments with laboratory animals of the Academy of Sciences of the Czech Republic.

Inbred C57BL/6 female mice (AnLab, Prague, Czech Republic) were housed at a temperature of $23^{\circ} \mathrm{C}$ under a daily cycle of 12 hours light and dark (light from 6:00 a.m.) with free access to water and food pellets (St-1, Mlýn Kocanda, Jesenice, Czech Republic). All mice were bilaterally ovariectomized at the age of five weeks (Matyšková et al., 2010).

\subsection{Acute effect of GHS-R antagonists on food intake}

Fifteen-week-old ovariectomized mice were placed into separate cages for one week. Before experiments, mice were fasted for $17 \mathrm{~h}$ with free access to water and then were injected subcutaneously (SC) with $0.2 \mathrm{ml}$ of saline, [D-Lys ${ }^{3}$ ]GHRP-6 or SPa (dissolved in saline) in a dose ranging from $1-10 \mathrm{mg} / \mathrm{kg}$ ( $\mathrm{n}=6-8$ mice per group). Fifteen minutes after the injection, mice were given pre-weighed food pellets. Food intake was followed for $5 \mathrm{~h}$; the pellets were weighed at 30 min intervals and then replaced with fresh ones, and cumulative food intake was registered. Animals had free access to water during the experiments.

\subsection{Behavioral studies}

\subsubsection{Open-field locomotor activity}

Locomotor activity was measured using the VideoMot system (TSE Systems, Bad Homburg, Germany). Fed fifteen-week-old ovariectomized mice were placed individually into a cylindrical open field, and their exploratory activity, i.e., number of rearings, was 
monitored for $10 \mathrm{~min}$. Testing started $15 \mathrm{~min}$ after SC injection of [D-Lys ${ }^{3}$ ]GHRP-6 (10 $\mathrm{mg} / \mathrm{kg}$ ) or SPa (10 mg/kg), as described in feeding experiments ( $\mathrm{n}=6$ mice/group).

\subsubsection{Hot-plate analgesic test}

Analgesia was measured by a hot-plate analgesia meter (TSE Systems, Bad

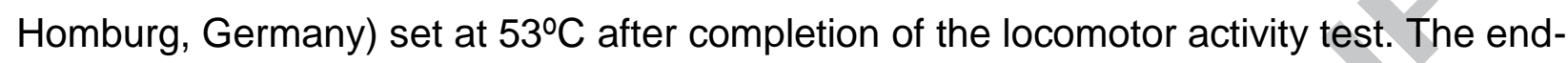
point was the latency to jump, after which the animals were immediately removed from the plate.

\subsection{Measurement of pharmacokinetics in the blood serum}

Fifteen-week-old ovariectomized mice were SC injected with [D-Lys ${ }^{3}$ ]GHRP-6 or SPa, at a dose of $10 \mathrm{mg} / \mathrm{kg}$ or with saline and sacrificed $10,40,130,310$ or $480 \mathrm{~min}$ after injection $(n=3)$. Their blood was collected, and blood sera were isolated and stored at $20^{\circ} \mathrm{C}$. Peptides were extracted using an acetonitrile precipitation as described in (Hatziieremia et al., 2007) and then subjected to an LC-MS system consisting of an HPLC Alliance (Waters, USA) and a Q-TOF-Micro hybrid mass spectrometer (Waters, USA). Chromatographic separation was carried out with a Discovery HS C18 column (Supelco, USA), with a particle size of $5 \mu \mathrm{m}$ and a column size of $5 \times 2.1 \mathrm{~mm}$ ID that was equipped with a guard column of $2 \times 2.1 \mathrm{~mm} \mathrm{ID}$ and packed with the same sorbent. The mobile phase A consisted of $0.1 \% \mathrm{HCOOH}$ in water, and the mobile phase $\mathrm{B}$ contained $0.1 \% \mathrm{HCOOH}$ in acetonitrile. For the separation of analytes, a gradient from $100 \%$ A to $100 \%$ B over 3 min was used at a flow rate of $200 \mu \mathrm{l} / \mathrm{min}$. MS conditions were as follows: ES+, capillary $2700 \mathrm{~V}$, sample cone $42 \mathrm{~V}$, extraction cone $1.0 \mathrm{~V}$, source temperature $100{ }^{\circ} \mathrm{C}$, desolvation temperature $250^{\circ} \mathrm{C}$, cone gas flow $10 \mathrm{l} / \mathrm{h} \mathrm{N}$, desolvation gas flow $250 \mathrm{l} / \mathrm{h} \mathrm{N}$. 


\subsection{Effect of seven days of GHS-R antagonist administration on food intake and metabolic parameters in obese and lean ovariectomized mice with or without estrogen supplementation}

At 8 weeks of age, ovariectomized mice were divided into a standard (St) diet-fed group (the energy content of the St-1 diet was $3.4 \mathrm{kcal} / \mathrm{g}$, containing 25,9 , and $66 \%$ of calories from protein, fat, and carbohydrate, respectively (St-1, Mlýn Kocanda, Jesenice, Czech Republic)) and an HF diet-fed group (the energy content of the HF diet was $5.3 \mathrm{kcal} / \mathrm{g}$, containing 13,60 , and $27 \%$ of calories from protein, fat, and carbohydrate, respectively). The HF diet consisted of $40 \%$ standard St-1 diet, $34 \%$ powdered cow milk for human neonates, 25\% lard, and 1\% corn starch w/w (Kopecký et al., 1996). Food intake and body weight were monitored weekly from 9 to 27 weeks of age. Mice resistant to the HF diet were withdrawn from the experiment (approximately $10 \%$ of mice).

The following four groups of mice were established at 24 weeks of age, when $17 \beta-$ estradiol-3-benzoate (E2) supplementation was initiated:

1. OVX/St: ovariectomized mice fed the St diet.

2. OVX/HF: ovariectomized mice fed the HF diet.

3. OVX/St + E2: ovariectomized mice fed the St diet with E2 supplementation.

4. OVX/HF + E2: ovariectomized mice fed the HF diet with E2 supplementation.

Supplementation with E2 (8 $\mu \mathrm{g} / \mathrm{mouse}$, dissolved in sesame oil; Sigma, St. Louis, USA) was performed every four days for four weeks (Clegg et al., 2006). Synchronization of the estrous cycle was demonstrated from the cell phenotype of vaginal smears.

At the age of 27 weeks, mice were placed into separate cages with free access to food and water. The following week, mice were subjected to a 7-day food intake experiment. They were injected with [D-Lys $\left.{ }^{3}\right]$ GHRP-6 or SPa at doses of $10 \mathrm{mg} / \mathrm{kg}$ 
$(n=10)$ or saline twice a day (at 8:00 and 18:00) for seven days. Consumption of the St or HF diet and the weight of the mice were simultaneously followed.

Pair-fed mice were given the same amount of St or HF food consumed by the compound-treated mice on the previous day. After 7 days of treatment either with [DLys $^{3}$ ]GHRP-6 or SPa, mice were fasted overnight and sacrificed the following morning. Their blood sera were isolated, and the white adipose tissue (subcutaneous, abdominal, and gonadal), the brown adipose tissue (BAT), the calf muscle and the liver of all mice were dissected, weighed, and stored at $-70^{\circ} \mathrm{C}$. Fat to body weight ratio was calculated as a ratio of adipose tissue weight to body weight.

\subsection{Determination of hormonal and biochemical parameters}

Serum insulin and adiponectin concentrations were measured by RIA assays, and leptin and fibroblast growth factor 21 (FGF21) concentrations were determined by ELISA assays (Linco Research, St. Charles, MI, USA). Serum glucose levels were measured using a Glucocard glucometer (Arkray, Kyoto, Japan), and levels of $\beta$ hydroxybutyrate were determined by an Optium Xceed glucometer (Abbot, Witney, UK) using $\beta$-ketone test strips. Serum triglyceride levels were measured by quantitative enzymatic reactions (Sigma, St. Louis, USA).

\subsection{Determination of $m R N A$ expression}

Samples of adipose tissue (brown, subcutaneous, abdominal plus gonadal), liver and muscle were homogenized with a MagNA Lyser Instrument using MagNA Lyser Green Beads (Roche Diagnostics GmbH, Mannheim, Germany). Total RNA was extracted from the homogenized samples with a MagNA Pure instrument using a MagNA Pure Compact RNA Isolation (Tissue) kit (Roche Diagnostics GmbH, Mannheim, Germany).

The RNA concentration was determined from the absorbance at $260 \mathrm{~nm}$ (BioPhotometer, Eppendorf AG, Hamburg, Germany). The integrity of the RNA was 
checked by visualization of the $18 \mathrm{~S}$ and $28 \mathrm{~S}$ ribosomal bands on $1 \%$ agarose gels with a GelRed ${ }^{\mathrm{TM}}$ Nucleic Acid GelStain. For reverse transcription to synthesize first-strand cDNA, $0.25 \mu \mathrm{g}$ of total RNA was used with random primers, following the instructions of the High-Capacity cDNA Reverse Transcription Kit (Applied Biosystems, Foster City, CA, USA). Determination of the mRNA expression of genes of interest (UCP1 in BAT; FGF21 in liver, muscle, subcutaneous and abdominal plus gonadal adipose tissue; GLUT-1 in subcutaneous and abdominal plus gonadal adipose tissue; peroxisome proliferator-activated receptor alpha (PPAR-alpha) in liver) was performed using an $A B I$ PRISM 7500 instrument (Applied Biosystems, Foster City, CA, USA) with TaqMan ${ }^{\circledR}$ Universal PCR Master Mix, NO AmpErase ${ }^{\circledR}$ UNG and specific TaqMan ${ }^{\circledR}$ Gene Expression Assays (Applied Biosystems, Foster City, CA, USA) and nuclease-free water (Fermentas Life Science, Vilnius, Lithuania). PCR amplifications were performed at least in duplicate in a total reaction volume of $25 \mu \mathrm{l}$. The PCR reactions were performed according to standard conditions $\left(50^{\circ} \mathrm{C}\right.$ for $2 \mathrm{~min}, 95^{\circ} \mathrm{C}$ for $10 \mathrm{~min}$, followed by 40 cycles of $95^{\circ} \mathrm{C}$ for $15 \mathrm{~s}, 60^{\circ} \mathrm{C}$ for $\left.1 \mathrm{~min}\right)$. The expression of beta-2-microglobulin (B2M) was used to compensate for variations in input RNA amounts and the efficiency of reverse transcription, and the modified formula $2^{-\Delta \mathrm{Ct}}$ was used for calculation of relative gene expression.

\subsection{Statistical analysis}

The data are presented as means \pm SEM for the number of animals indicated in the Figures and Tables. They were analyzed by a one-way ANOVA followed by a Tukey post-hoc test (metabolic parameters, behavioral study) or two-way ANOVA followed by a Bonferroni post-hoc test (food intake and body weight evaluation) using Graph-Pad Software (San Diego, CA, USA). P $<0.05$ was considered statistically significant. In the 
acute food intake test, the $E D_{50}$ value was the dose required to obtain half of the response of the saline-treated group.

\section{Results}

\section{Acute effects of GHS-R antagonists in lean mice}

In the first part of this study, the acute anorexigenic effects of the ghrelin antagonist $\left[D-\right.$ Lys $\left.^{3}\right]$ GHRP-6 and the ghrelin inverse agonist SPa were determined in fifteen-weekold OVX/St mice using doses from 1 to $10 \mathrm{mg} / \mathrm{kg}$, which were similar to those used by Asakawa et al. (Asakawa et al., 2003). Both [D-Lys ${ }^{3}$ GHRP-6 and SPa reduced food intake in fasted mice in a dose-dependent manner, with an $\mathrm{ED}_{50}$ value in a range of $\mathrm{mg} / \mathrm{kg}$ (Table 1). Analogously, short-term anorexigenic test was carried out also in OVX/HF mice (after 2 months on HF diet). The results were similar to that obtained with OVX/St group - a single dose of $10 \mathrm{mg} / \mathrm{kg}$ of [D-Lys ${ }^{3}$ GHRP-6 or SPa totally inhibited food intake for $45 \mathrm{~min}$, the decrease of food intake was significant for next 2-3 hours compared to relevant saline-treated group. Dose-response experiment showed that $\mathrm{ED}_{50}$ for [D-Lys $\left.{ }^{3}\right] \mathrm{GHRP}-6$ was $4,3 \pm 1,6 \mathrm{mg} / \mathrm{kg}$ at $45 \mathrm{~min}$ after administration to fasted OVX/HF mice.

Table 1 also shows the times and values of the maximal blood concentrations of [DLys $^{3}$ ]GHRP-6 and SPa after a single subcutaneous administration at a dose of 10 $\mathrm{mg} / \mathrm{kg}$ to fifteen-week-old OVX/St mice. [D-Lys ${ }^{3}$ ]GHRP-6 had $\mathrm{T}_{\max }$ of $10 \mathrm{~min}$ and then dropped sharply, reaching a zero concentration at $130 \mathrm{~min}$. SPa showed a longer halflife than $\left[\mathrm{D}-\mathrm{Lys}^{3}\right]$ GHRP-6, with a $\mathrm{T}_{\max }$ of $40 \mathrm{~min}$ and complete disappearance at 310 $\min$.

To determine possible sedative or analgesic effects of the tested compounds that could affect food intake, open field activity and analgesia were measured after the 
administration of $\left[\mathrm{D}-\mathrm{Lys}^{3}\right]$ GHRP-6 or SPa in fifteen-week-old OVX/St mice. Both peptides significantly reduced exploratory activity in the open field test and caused analgesia in the hot plate test (Table 1). However, these effects lasted for only approximately $30 \mathrm{~min}$ and, therefore, could not have substantially influenced long-term food intake.

\subsection{Effects of seven days of GHS-R antagonist administration in a OVX mice}

After eighteen weeks of feeding on the HF diet, the body weight of OVX mice was about $60 \%$ higher than that of OVX mice fed the St diet (Fig. 1). Estrogen supplementation from 24 weeks of age reduced the body weight in OVX females on the HF diet, and it also tended to have this effect in mice on a standard diet, although the difference in this latter group did not reach statistical significance (Fig. 1).

Our preliminary study showed that use of a dose of $5 \mathrm{mg} / \mathrm{kg}$ of [D-Lys $\left.{ }^{3}\right]$ GHRP-6 in one week experiment did not result in a significant lowering of food intake and body weight (results not shown). Therefore, a dose of $10 \mathrm{mg} / \mathrm{kg}$ injected SC two times per day was chosen for the seven-days administration.

Seven days of treatment with [D-Lys ${ }^{3}$ GHRP-6 at a dose of $10 \mathrm{mg} / \mathrm{kg}$ of body weight reduced the average daily energy intake by 84 and $61 \%$ in the HF- and St-fed OVX mice, respectively, compared with the saline-treated controls (Fig. 2A) and significantly decreased body weight (Fig. 2C,B). In the HF-diet-fed OVX mice, seven days of treatment with [D-Lys ${ }^{3}$ GGHR-6 markedly decreased the fat/body weight ratio, blood leptin, glucose, and insulin levels and HOMA index (Table 2). Pair-fed mice on the HF diet, which received the same amount of food as the [D-Lys ${ }^{3}$ GHRP-6-treated mice, showed a loss of body weight similar to that of the [D-Lys ${ }^{3}$ GHRP-6-treated animals. In the pair-fed mice, the fat/body weight ratio, glucose, insulin levels and HOMA index were also significantly decreased; decrease in leptin did not reach statistical 
significance (Table 2). $\beta$-hydroxybutyrate levels were significantly increased both in the [D-Lys ${ }^{3}$ ]GHRP-6-treated and HF-fed mice and pair-fed mice, compared to the control group (Table 2). Adiponectin levels in OVX/HF mice both treated with [D-Lys ${ }^{3}$ ]GHRP-6 and in pair-fed were increased, but insignificantly (Table 2).

In the St-diet-fed OVX mice without estrogen supplementation, a significant decrease in food intake (Fig. 2A) and body weight (Fig. 2B) after [D-Lys $\left.{ }^{3}\right]$ GHRP-6 treatment was followed by decreased glucose level compared to saline-injected control mice (Table 2). Similar effects were seen in pair-fed mice with St diet, where decrease in insulin level was significant and resulted in a significantly decreased HOMA index (Table 2). Both in [D-Lys ${ }^{3}$ ]GHRP-6-treated and pair-fed OVX mice on St diet, increase in adiponectin was significant. Similarly to the effect observed in HF diet-fed mice, increased levels of $\beta$ hydroxybutyrate were found after both [D-Lys ${ }^{3}$ GHRP-6 treatment and pair feeding in mice on St diet (Table 2).

Estrogen supplementation to OVX mice both on the St and HF diets resulted in a decreased [D-Lys ${ }^{3}$ ]GHRP-6 anorexigenic effect, with only a 17 and $18 \%$ decrease in energy intake after 7-day-treatment compared to saline treated group, respectively (Fig. 2D). Additionally, there was a less pronounced decrease in body weight when compared to the OVX mice that were not treated with estrogen (Fig. 2E,F) and no significant changes in the measured metabolic parameters were observed (Table 2).

Despite the promising anorexigenic effects of SPa observed in the acute short-term test and the longer blood half-life of SPa (Table 1), seven day application of SPa did not significantly affect food intake, body weight, or metabolic parameters (Fig. S1 and Table S1).

\subsection{Expression of UCP1 in BAT}


UCP1 mRNA levels in the BAT of OVX mice fed the St and HF diets after seven days of treatment with [D-Lys $\left.{ }^{3}\right]$ GHRP-6 or pair-feeding are summarized in Fig. 3. UCP1 mRNA expression was significantly increased in mice treated with [D-Lys ${ }^{3}$ ]GHRP-6 fed the St and HF diet, while in pair-fed mice, the UCP1 mRNA level significantly increased only in mice on the St diet.

\subsection{Decreased food intake induced expression of FGF-21 in the liver and GLUT-1}

\section{in fat}

The markedly decreased food intake resulting from [D-Lys ${ }^{3}$ ]GHRP-6 treatment or pairfeeding was accompanied by an increase in ketone bodies in the OVX mice fed the HF and St diets. Recently, starvation-induced rise in ketone bodies was linked to induction of FGF21, a key mediator of hepatic lipid metabolism at fasting and ketogenic diet (Badman et al., 2007; Kharitonenkov et al., 2005; Reitman, 2007). This finding inspired us to measure FGF-21 level in blood and mRNA expression in the liver. In the salinetreated controls, similar FGF21 serum concentrations were detected regardless of diet and estrogen state (Fig. 4). In the OVX mice on the St diet, either with or without estrogen supplementation, neither [D-Lys $\left.{ }^{3}\right]$ GHRP-6 treatment nor pair-feeding significantly affected the FGF21 level. In contrast, a twenty-fold increase in circulating FGF21 levels occurred in HF diet-fed OVX mice, both after [D-Lys ${ }^{3}$ ]GHRP-6 treatment and in the corresponding pair-fed group (Fig. 4). The increase in secreted FGF21 after [D-Lys ${ }^{3}$ GHRP-6 treatment or pair-feeding in OVX mice fed the HF diet resulted from significantly enhanced FGF21 expression in the liver (Fig. 5A). A significant increase in FGF21 expression was also found in the subcutaneous, but not the visceral, fat and muscle (Fig. 5B,C). Interestingly, pair-fed OVX mice on the HF diet also displayed very significantly enhanced FGF21 expression in their muscle, while this change was not observed in the [D-Lys $\left.{ }^{3}\right]$ GHRP-6-treated animals (Fig. 5D). 
PPAR-alpha expression in the liver was decreased insignificantly (Fig. 6C), and GLUT-1 expression following [D-Lys ${ }^{3}$ GHRP-6 treatment was enhanced significantly in the abdominal, but not the subcutaneous, fat of the OVX mice on the HF diet (Fig. $6 A, B)$.

\section{Discussion}

The obesity epidemic calls for novel pharmacologic treatment methods. This issue became even more urgent after rimonabant and sibutramine were withdrawn from the market. The inhibition of ghrelin action seems to represent a promising approach, as it attenuates food intake and subsequently improves other pathologies and metabolic parameters clustered within the so-called metabolic or insulin-resistance syndrome. Here, we performed experiments with two peptides that antagonize ghrelin action in a model of postmenopausal obesity. Interestingly, the ghrelin inverse agonist SPa that exhibited similar dose-dependent acute anorexigenic effects and higher stability in the blood than [D-Lys ${ }^{3}$ GHRP-6, did not exert a significant influence on food intake or body weight in the seven day-long study. High basal activity of the ghrelin receptor and its inhibition by inverse agonists, such as SPa, have been recently demonstrated through phosphorylation of c-AMP response element binding protein (CREB) in hypothalamic cells constitutively expressing the ghrelin receptor (Petersen et al., 2009). SPa is considered to act as an inverse agonist with a low antagonist action (Holst et al., 2009); however, in our study it did not prove to inactivate significantly the ghrelin receptor in a seven-day-long study. The reason for the SPa ineffectiveness in our study is not clear but might involve the non-selective activity of $\mathrm{SPa}$, which binds not only to GHS-R but also to the neurokinin (Djanani et al., 2003) and bombesin (MacKinnon et al., 2001) receptors. 
On the other hand, we demonstrated here clear anorexigenic properties of [DLys $^{3}$ ]GHRP-6 both in an acute and a longer treatment, with the most significant effects being found in a mouse model of postmenopausal obesity/estrogen-deficiency with an HF diet.

A powerful long-term effect of the ghrelin antagonist [D-Lys ${ }^{3}$ GHRP-6 in reducing food intake and body weight was accompanied by decreased blood glucose and increased the $\beta$-hydroxybutyrate level in OVX mice fed St and HF diets. OVX mice pair-fed HF diet exhibited significantly attenuated insulin levels and HOMA index similarly as [DLys $^{3}$ ]GHRP-6-treated ones, suggesting that the most important mechanism of action of [D-Lys ${ }^{3}$ GHRP-6 lies in the inhibition of food intake. In contrast, in the pair-fed OVX mice receiving the St diet, glucose, insulin and the HOMA index were reduced, and adiponectin levels were increased more significantly than in the [D-Lys ${ }^{3}$ GGHRP-6treated animals. Increased adiponectin levels may represent a mechanism that leads to improved glucose metabolism in these animals (Ahima and Lazar, 2008).

Previous studies have found that estrogen suppresses food intake and activates STAT3 in the brain, similarly to leptin. The estrogen effects were found to be independent of leptin, and they were able to substitute for leptin anorexigenic effects in leptin- or leptin-receptor deficient mice (Gao et al., 2007). Similarly in our study, in marked diet-induced obesity, which is also considered to be a leptin-resistant state (Matyšková et al., 2010), four weeks of estrogen supplementation significantly decreased the body weight of OVX mice fed on HF diet and normalized metabolic parameters.

Ghrelin is considered to be a functional antagonist of leptin. Additionally, the orexigenic potency of ghrelin in female mice was shown to be reduced by estrogen (Clegg et al., 2007). Similarly, in our study, it was found that the ghrelin antagonist [D- 
Lys $^{3}$ ]GHRP-6 was most effective under a state of combined estrogen deficiency and leptin resistance.

Brown adipose tissue contains numerous mitochondria with UCP1 located on mitochondrial membrane that play an important role in energy dissipation. In our study, in addition to decreasing food intake, [D-Lys $\left.{ }^{3}\right]$ GHRP-6 significantly increased the mRNA expression of UCP1 in BAT in both the OVX/St and OVX/HF groups, suggesting enhanced energy dissipation (Fig. 3). This finding is in agreement with a study by ManoOtagiri et al. (Mano-Otagiri et al., 2010), where transgenic rats expressing antisense GHS-R mRNA showed increased UCP1 expression in BAT compared with wild-type rats. Analogously, gastrectomy in mice, which was aimed at the elimination of the most abundant source of ghrelin, resulted in reduced expression of UCP1 in BAT (Lindqvist et al., 2007). On the contrary, chronic ghrelin treatment in lean male mice decreased the expression of UCP1 in brown adipose tissue (Tsubone et al., 2005).

The long-term anorexigenic action of [D-Lys ${ }^{3}$ ]GHRP-6 led to an 84 or $61 \%$ decrease in the daily energy intake in the HF- and St-fed OVX mice, respectively, which was followed by a significant increase in the level of $\beta$-hydroxybutyrate. Recently, it was suggested that under fasting conditions and simultaneously with the synthesis of ketone bodies, PPARa is activated and directly induces the expression of fibroblast growth factor 21 (FGF21) (Badman et al., 2007; Cuevas-Ramos et al., 2009; Dostálová et al., 2009), which was proposed as a "missing link" in the biology of fasting (Reitman, 2007). FGF21 treatment has been recently shown to reduce body weight, body fat, blood glucose, insulin and lipid levels without affecting food intake in ob/ob mice and mice with DIO (Coskun et al., 2008; Xu et al., 2009). Finally, FGF21 induced upregulation of GLUT1 in adipose cells both in vitro and in vivo, but insulin-dependent GLUT4 was not affected (Kharitonenkov et al., 2005). 
Therefore, we studied the changes in the circulating levels and mRNA expression of FGF21 to determine its possible role in the metabolic changes induced by [DLys $^{3}$ ]GHRP-6. In the OVX mice on the HF diet, we found a profound increase of liver FGF21 mRNA expression after [D-Lys ${ }^{3}$ ]GHRP-6 administration and a twenty-fold increase of circulating FGF21 levels (Fig. 4). A similar increase in FGF21 was noted in the associated pair-fed group (Fig. 4, 5). FGF21 was shown to be induced not only by fasting but also by a ketogenic diet (Badman et al., 2007). [D-Lys ${ }^{3}$ GHRP-6 treatment or pair-feeding resulted in reduced consumption of the HF diet which subsequently contributed to the ketogenic state. This explains why in the [D-Lys ${ }^{3}$ GHRP-6-treated OVX mice fed the St diet, FGF21 production was not increased despite a significant increase in ketone bodies. These findings suggest that a combination of decreased food intake and the more ketogenic HF diet induced massive expression and secretion of FGF21.

FGF21 expression in the liver is considered to be directed by PPAR-alpha activation (Badman et al., 2007). In this study, PPAR-alpha expression in the liver tended to be decreased rather than increased, suggesting that at least the mRNA expression levels of FGF21 could be increased without significantly enhancing the mRNA expression of PPAR-alpha. FGF21 was shown to mediate insulin-independent glucose uptake into adipose tissue via increased expression of GLUT-1 (Badman et al., 2007). Similarly in this study, the enhanced FGF21 production could directly contribute to an increase in GLUT-1 expression in abdominal fat of [D-Lys $\left.{ }^{3}\right]$ GHRP-6-treated mice.

\section{Conclusion}

In conclusion, our study demonstrated a marked beneficial, primary anorexigenic effect of [D-Lys $\left.{ }^{3}\right]$ GHRP-6 on obesity and metabolic parameters that was especially pronounced in an experimental model of postmenopausal obesity, using OVX mice with 
HF diet induced DIO. Our data support the hypothesis that ghrelin antagonists, such as [D-Lys ${ }^{3}$ ]GHRP-6, could be especially efficient under conditions of obesity combined with estrogen deficiency. Ketonic states resulting from [D-Lys $\left.{ }^{3}\right]$ GHRP-6-induced fasting and ketogenic HF diet increased substantially production of FGF21 that could also exert positive metabolic effects.

\section{Acknowledgements}

We gratefully acknowledge the excellent technical assistance of $A$. Vytejčková and $H$. Vysušilová. This work was supported by grants 303/09/0614 of the Grant Agency of the Czech Republic, Z40550506 of the Academy of Sciences of the Czech Republic, MSM0021620814 from Czech Ministry of Health and MSM 6046137307 from the Ministry of Education of the Czech Republic.

\section{References}

Ahima, R., Lazar, M., 2008. Adipokines and the peripheral and neural control of energy balance. Mol Endocrinol 22, 1023-1031.

Asakawa, A., Inui, A., Kaga, T., Katsuura, G., Fujimiya, M., Fujino, M., Kasuga, M., 2003. Antagonism of ghrelin receptor reduces food intake and body weight gain in mice. Gut 52, 947-952.

Badman, M., Pissios, P., Kennedy, A., Koukos, G., Flier, J., Maratos-Flier, E., 2007. Hepatic fibroblast growth factor 21 is regulated by PPARalpha and is a key mediator of hepatic lipid metabolism in ketotic states. Cell Metab 5, 426-437.

Brown, L., Clegg, D., 2010. Central effects of estradiol in the regulation of food intake, body weight, and adiposity. J Steroid Biochem Mol Biol 122, 65-73.

Castañeda, T., Tong, J., Datta, R., Culler, M., Tschöp, M., 2010. Ghrelin in the regulation of body weight and metabolism. Front Neuroendocrinol 31, 44-60.

Cheng, K., Wei, L., Chaung, L., Chan, W., Butler, B., Smith, R., 1997. Inhibition of L692,429 -stimulated rat growth hormone release by a weak substance P antagonist: L756,867. J Endocrinol 152, 155-158.

Chollet, C., Meyer, K., Beck-Sickinger, A., 2009. Ghrelin--a novel generation of antiobesity drug: design, pharmacomodulation and biological activity of ghrelin analogues. J Pept Sci 15, 711-730.

Clegg, D., Brown, L., Woods, S., Benoit, S., 2006. Gonadal hormones determine sensitivity to central leptin and insulin. Diabetes 55, 978-987. 
Clegg, D., Brown, L., Zigman, J., Kemp, C., Strader, A., Benoit, S., Woods, S., Mangiaracina, M., Geary, N., 2007. Estradiol-dependent decrease in the orexigenic potency of ghrelin in female rats. Diabetes 56, 1051-1058.

Coskun, T., Bina, H., Schneider, M., Dunbar, J., Hu, C., Chen, Y., Moller, D., Kharitonenkov, A., 2008. Fibroblast growth factor 21 corrects obesity in mice. Endocrinology 149, 6018-6027.

Cuevas-Ramos, D., Almeda-Valdes, P., Aguilar-Salinas, C., Cuevas-Ramos, G., Cuevas-Sosa, A., Gomez-Perez, F., 2009. The role of fibroblast growth factor 21 (FGF21) on energy balance, glucose and lipid metabolism. Curr Diabetes Rev 5, 216 220.

Djanani, A., Kaneider, N., Sturn, D., Wiedermann, C., 2003. Agonist function of the neurokinin receptor antagonist, [D-Arg1,D-Phe5,D-Trp7,9,Leu11]substance $P$, in monocytes. Regul Pept 115, 123-129.

Dostálová, I., Haluzíková, D., Haluzík, M., 2009. Fibroblast growth factor 21: a novel metabolic regulator with potential therapeutic properties in obesity/type 2 diabetes mellitus. Physiol Res 58, 1-7.

Esler, W., Rudolph, J., Claus, T., Tang, W., Barucci, N., Brown, S., Bullock, W., Daly, M., Decarr, L., Li, Y., Milardo, L., Molstad, D., Zhu, J., Gardell, S., Livingston, J., Sweet, L., 2007. Small-molecule ghrelin receptor antagonists improve glucose tolerance, suppress appetite, and promote weight loss. Endocrinology 148, 51755185.

Gao, Q., Mezei, G., Nie, Y., Rao, Y., Choi, C., Bechmann, I., Leranth, C., ToranAllerand, D., Priest, C., Roberts, J., Gao, X., Mobbs, C., Shulman, G., Diano, S., Horvath, T., 2007. Anorectic estrogen mimics leptin's effect on the rewiring of melanocortin cells and Stat3 signaling in obese animals. Nat Med 13, 89-94.

Hatziieremia, S., Kostomitsopoulos, N., Balafas, V., Tamvakopoulos, C., 2007. A liquid chromatographic/tandem mass spectroscopic method for quantification of the cyclic peptide melanotan-II. Plasma and brain tissue concentrations following administration in mice. Rapid Commun Mass Spectrom 21, 2431-2438.

Holst, B., Frimurer, T., Mokrosinski, J., Halkjaer, T., Cullberg, K., Underwood, C., Schwartz, T., 2009. Overlapping binding site for the endogenous agonist, smallmolecule agonists, and ago-allosteric modulators on the ghrelin receptor. Mol Pharmacol 75, 44-59.

Kharitonenkov, A., Shiyanova, T.L., Koester, A., Ford, A.M., Micanovic, R., Galbreath, E.J., Sandusky, G.E., Hammond, L.J., Moyers, J.S., Owens, R.A., Gromada, J., Brozinick, J.T., Hawkins, E.D., Wroblewski, V.J., Li, D.S., Mehrbod, F., Jaskunas, S.R., Shanafelt, A.B., 2005. FGF-21 as a novel metabolic regulator. J Clin Invest 115, 1627-1635.

Kopecký, J., Hodný, Z., Rossmeisl, M., Syrový, I., Kozak, L., 1996. Reduction of dietary obesity in aP2-Ucp transgenic mice: physiology and adipose tissue distribution. Am J Physiol 270, E768-775.

Lindqvist, A., de la Cour, C., Håkanson, R., Erlanson-Albertsson, C., 2007. Ghrelin affects gastrectomy-induced decrease in UCP1 and beta3-AR mRNA expression in mice. Regul Pept 142, 24-28.

MacKinnon, A., Waters, C., Jodrell, D., Haslett, C., Sethi, T., 2001. Bombesin and substance $P$ analogues differentially regulate G-protein coupling to the bombesin receptor. Direct evidence for biased agonism. J Biol Chem 276, 28083-28091.

Maixnerová, J., Hlavácek, J., Blokesová, D., Kowalczyk, W., Elbert, T., Sanda, M., Blechová, M., Zelezná, B., Slaninová, J., Maletínská, L., 2007. Structure-activity 
relationship of CART (cocaine- and amphetamine-regulated transcript) peptide fragments. Peptides 28, 1945-1953.

Mano-Otagiri, A., Iwasaki-Sekino, A., Nemoto, T., Ohata, H., Shuto, Y., Nakabayashi, H., Sugihara, H., Oikawa, S., Shibasaki, T., 2010. Genetic suppression of ghrelin receptors activates brown adipocyte function and decreases fat storage in rats. Regul Pept 160, 81-90.

Matyšková, R., Zelezná, B., Maixnerová, J., Koutová, D., Haluzík, M., Maletínská, L., 2010. Estradiol Supplementation Helps Overcome Central Leptin Resistance of Ovariectomized Mice on a High Fat Diet. Horm Metab Res.

Moulin, A., Ryan, J., Martinez, J., Fehrentz, J., 2007. Recent developments in ghrelin receptor ligands. ChemMedChem 2, 1242-1259.

Nogueiras, R., Perez-Tilve, D., Wortley, K., Tschöp, M., 2006. Growth hormone secretagogue (ghrelin-) receptors--a complex drug target for the regulation of body weight. CNS Neurol Disord Drug Targets 5, 335-343.

Petersen, P., Woldbye, D., Madsen, A., Egerod, K., Jin, C., Lang, M., Rasmussen, M., Beck-Sickinger, A., Holst, B., 2009. In vivo characterization of high Basal signaling from the ghrelin receptor. Endocrinology 150, 4920-4930.

Reitman, M., 2007. FGF21: a missing link in the biology of fasting. Cell Metab 5, 405407.

Shi, H., Clegg, D., 2009. Sex differences in the regulation of body weight. Physiol Behav 97, 199-204.

Smith, R., Cheng, K., Schoen, W., Pong, S., Hickey, G., Jacks, T., Butler, B., Chan, W., Chaung, L., Judith, F., 1993. A nonpeptidyl growth hormone secretagogue. Science 260, 1640-1643.

Tena-Sempere, M., 2007. Roles of ghrelin and leptin in the control of reproductive function. Neuroendocrinology 86, 229-241.

Tsubone, T., Masaki, T., Katsuragi, I., Tanaka, K., Kakuma, T., Yoshimatsu, H., 2005. Ghrelin regulates adiposity in white adipose tissue and UCP1 mRNA expression in brown adipose tissue in mice. Regul Pept 130, 97-103.

Wortley, K., del Rincon, J., Murray, J., Garcia, K., lida, K., Thorner, M., Sleeman, M., 2005. Absence of ghrelin protects against early-onset obesity. J Clin Invest 115, 35733578.

Xu, J., Lloyd, D., Hale, C., Stanislaus, S., Chen, M., Sivits, G., Vonderfecht, S., Hecht, R., Li, Y., Lindberg, R., Chen, J., Jung, D., Zhang, Z., Ko, H., Kim, J., Véniant, M., 2009. Fibroblast growth factor 21 reverses hepatic steatosis, increases energy expenditure, and improves insulin sensitivity in diet-induced obese mice. Diabetes 58, 250-259.

Zigman, J., Nakano, Y., Coppari, R., Balthasar, N., Marcus, J., Lee, C., Jones, J., Deysher, A., Waxman, A., White, R., Williams, T., Lachey, J., Seeley, R., Lowell, B., Elmquist, J., 2005. Mice lacking ghrelin receptors resist the development of dietinduced obesity. J Clin Invest 115, 3564-3572. 


\section{Figure legends}

\section{Fig. 1}

Increased body weight of OVX mice on the St and HF diets ( $n=40$ mice per group). Mice were fed an HF diet from 8 to 27 weeks of age. The data were analyzed by two-way ANOVA (diet $x$ weeks of age). The significance levels were ${ }^{* *} \mathrm{P}<0.05$ and ${ }^{* * *} \mathrm{P}<0.001$ vs. the respective group on a St diet.

\section{Fig. 2}

\section{Long-term effect of [D-Lys $\left.{ }^{3}\right]$ GHRP-6 in a DIO/OVX model of mice (SC} administration, dose $10 \mathrm{mg} / \mathrm{kg}$, twice per day for 7 days): A) cumulative food intake in OVX/St and OVX/HF mice, B) change in body weight in OVX/St group, C) change in body weight in the OVX/HF group, D) cumulative food intake in OVX/St+E2 and $\mathrm{OVX} / \mathrm{HF}+\mathrm{E} 2$ mice, E) change in body weight in OVX/St+E2 group, F) change in body weight in the OVX/HF+E2 group ( $n=10$; for pair-fed groups: $n=5)$. The data were analyzed by two-way ANOVA (treatment $x$ time after injection). ${ }^{* * *} \mathrm{P}<0.001$ vs. respective saline-treated group.

\section{Fig. 3}

\section{Effect of [D-Lys ${ }^{3}$ ]GHRP-6 on the expression of BAT UCP1 mRNA in OVX/St and}

OVX/HF mice (SC administration, dose $10 \mathrm{mg} / \mathrm{kg}$, twice per day for 7 days) ( $\mathrm{n}=10$; for pair-fed groups: $n=5$ ). The data were analyzed by one-way ANOVA. ${ }^{* *}<0.01$ and ${ }^{* * *} \mathrm{P}<0.001$ vs. respective saline-treated group.

Fig. 4 


\section{Effect of [D-Lys ${ }^{3}$ GHRP-6 on FGF21 serum levels in a DIO/OVX mouse model} (SC administration, dose $10 \mathrm{mg} / \mathrm{kg}$, twice per day for 7 days) ( $\mathrm{n}=10$, for pair-fed groups: $\mathrm{n}=5$ ). The data were analyzed by one-way ANOVA. ${ }^{* *} \mathrm{P}<0.001$ vs. respective salinetreated group.

\section{Fig. 5}

Effect of [D-Lys ${ }^{3}$ ]GHRP-6 (SC administration, dose $10 \mathrm{mg} / \mathrm{kg}$, twice per day for 7 days) on FGF21 mRNA expression in liver, subcutaneous adipose tissue and abdominal plus gonadal adipose tissue in OVX/HF mice $(n=10$, for pair-fed groups: $\mathrm{n}=5$ ). The data were analyzed by one-way ANOVA. ${ }^{*}<0.05$ and ${ }^{* * *} \mathrm{P}<0.001$ vs. respective saline-treated group.

Fig. 6

Effect of [D-Lys ${ }^{3}$ ]GHRP-6 (SC administration, dose $10 \mathrm{mg} / \mathrm{kg}$, twice per day for 7 days): A) on GLUT-1 mRNA expression in subcutaneous adipose tissue and abdominal plus gonadal adipose tissue and B) on PPAR-alpha mRNA expression in liver in OVX/HF mice ( $n=10$; for pair-fed groups: $n=5)$. The data were analyzed by oneway ANOVA. ${ }^{\star \star} \mathrm{P}<0.001$ vs. respective saline-treated group.

Fig. S1

Long-term effect of SPa in a DIO/OVX model of mice (SC administration, dose 10 $\mathrm{mg} / \mathrm{kg}$, twice per day for 7 days): A) cumulative food intake, B) change in body weight in OVX/St group, C) change in body weight in the OVX/HF group $(n=10$; for pair-fed groups: $n=5$ ). The data were analyzed by two-way ANOVA (treatment $x$ time after injection). There were no significant changes. 
Table 1

Short-term experiments in 15-week-old OVX/St mice

Compound Food intake Pharmaco kinetics in serum Behavioral studies at $45 \mathrm{~min}$

Open field Hot plate

$\begin{array}{llll}E_{50} & \mathrm{~T}_{\max } & \mathrm{C}_{\max } & \mathrm{AUC}\end{array}$

$(\mathrm{mg} / \mathrm{kg})$

$(\mu \mathrm{g} / \mathrm{ml}) \quad(\mu \mathrm{g} / \mathrm{ml} / \quad$ treated treated

480min) group) group)

$\begin{array}{lllllll}\text { [D-Lys }^{3} \text { ] } & 4.9 \pm 1.4 & 10 \mathrm{~min} & 6.7 & 731 & 0 & 230\end{array}$

GHRP-6

SPa

$3.0 \pm 1.6 \quad 40 \mathrm{~min}$

4.4

903

$0 \quad 144$

In pharmacokinetic and behavioral studies, both compounds were injected SC in a dose $10 \mathrm{mg} / \mathrm{kg} . E_{50}$ is a dose required to attenuate $50 \%$ of response of saline-treated group at the time of maximal response (45 min after injection). $T_{\max }-$ time at $\mathrm{C}_{\max }$ (maximal concentration of peptide in blood). AUC - area under curve (in concentration of peptide in blood as a function of time). In open field test, a number of rearings in 10 min after SC injection (dose $10 \mathrm{mg} / \mathrm{kg}$ ) was measured and compared with a number of rearings of saline treated group (in \%). In hot plate test, latency to jump was measured (after hot plate test) and compared with that of saline treated group (in \%) $(n=5)$. 
Table 2 Metabolic parameters after seven-days SC administration of [D-Lys ${ }^{3}$ GHRP-6 in 17h fasted female mice

\begin{tabular}{|c|c|c|c|c|c|c|c|c|}
\hline Group/treatment & $\begin{array}{c}\text { Fat/body weight } \\
{[\%]}\end{array}$ & $\begin{array}{l}\text { Leptin } \\
{[\mathrm{ng} / \mathrm{ml}]}\end{array}$ & $\begin{array}{l}\text { Glucose } \\
{[\mathrm{mmol} / \mathrm{l}]}\end{array}$ & $\begin{array}{l}\text { Insulin } \\
\text { [ng/ml] }\end{array}$ & HOMA & $\begin{array}{c}\text { Adiponectin } \\
{[\mu \mathrm{g} / \mathrm{ml}]}\end{array}$ & $\begin{array}{c}\text { Triglycerides } \\
\text { [mg/dl] }\end{array}$ & $\begin{array}{l}\text { B-hydroxy- } \\
\text { butyrate } \\
\text { [mmol/l/] }\end{array}$ \\
\hline \multicolumn{9}{|l|}{$\mathrm{A} / \mathrm{OVX} / \mathrm{St}$} \\
\hline Saline & $7,68 \pm 1,47$ & $11,81 \pm 5,46$ & $6,25 \pm 0,77$ & $0,96 \pm 0,27$ & $51,48 \pm 19,01$ & $22,70 \pm 1,80$ & $75,69 \pm 5,84$ & $1,29 \pm 0.18$ \\
\hline [D-Lys $\left.{ }^{3}\right]$ GHRP-6 & $6,16 \pm 0,89$ & $3,72 \pm 1,40$ & $4,51 \pm 0,19$ * & $0,38 \pm 0,09$ & $13,75 \pm 3,58$ & $28,25 \pm 0,93$ * & $62,97 \pm 4,86$ & $5,05 \pm 0.47^{* *}$ \\
\hline pair-fed & $7,11 \pm 0,48$ & $8,59 \pm 1,28$ & $3,90 \pm 0,39++$ & $0,19 \pm 0,01+$ & $5,53 \pm 0,47+$ & $31,54 \pm 2,20++$ & $72,57 \pm 5,22$ & $6,63 \pm 0.46^{* * *}$ \\
\hline \multicolumn{9}{|l|}{$\mathrm{B} / \mathrm{OVX} / \mathrm{HF}$} \\
\hline Saline & $15,12 \pm 0,37$ & $54,97 \pm 5,80$ & $7,17 \pm 0,28$ & $2,48 \pm 0,36$ & $137,82 \pm 22,70$ & $22,77 \pm 0,91$ & $83,82 \pm 4,14$ & $0,83 \pm 0.07$ \\
\hline [D-Lys $\left.{ }^{3}\right]$ GHRP-6 & $11,92 \pm 0,41^{* * *}$ & $22,65 \pm 3,25$ *** & $4,15 \pm 0,33^{* * *}$ & $0,48 \pm 0,10^{* * *}$ & $15,67 \pm 4,09 * * *$ & $24,43 \pm 1,45$ & $69,97 \pm 8,49$ & $3,56 \pm 0.21$ * \\
\hline pair-fed & $13,08 \pm 0,54+++$ & $43,66 \pm 4,12$ & $3,78 \pm 0,15+++$ & $0,27 \pm 0,06+++$ & $8,05 \pm 1,79+++$ & $25,35 \pm 1,97$ & $67,80 \pm 5,84$ & $6,95 \pm 0.44^{* * *}$ \\
\hline \multicolumn{9}{|l|}{$\mathrm{C} / \mathrm{OVX} / \mathrm{St}+\mathrm{E} 2$} \\
\hline Saline & $2,80 \pm 0,45$ & $3,22 \pm 1,13$ & $5,26 \pm 0,31$ & $0,20 \pm 0,06$ & $8,15 \pm 2,99$ & $14,47 \pm 1,86$ & $79,88 \pm 11,80$ & $0,90 \pm 0.18$ \\
\hline [D-Lys $\left.{ }^{3}\right]$ GHRP-6 & $2,25 \pm 0,17$ & $0,51 \pm 0,07$ * & $4,91 \pm c$ & $0,08 \pm 0,01$ & $2,81 \pm 0,47$ & $16,03 \pm 2,65$ & $76,69 \pm 7,58$ & $1,65 \pm 0.03$ \\
\hline pair-fed & $1,89 \pm 0,62$ & $1,50 \pm 0,26$ & $4,70 \pm 0,34$ & $0,13 \pm 0,03$ & $4,78 \pm 1,08$ & $16,88 \pm 3,72$ & $56,03 \pm 2,76$ & $1,45 \pm 0.24$ \\
\hline \multicolumn{9}{|l|}{$\mathrm{D} / \mathrm{OVX} / \mathrm{HF}+\mathrm{E2}$} \\
\hline Saline & $8,10 \pm 0,58$ & $6,63 \pm 1,04$ & $4,95 \pm 0,22$ & $0,46 \pm 0,05$ & $17,80 \pm 2,48$ & $8,14 \pm 0,72$ & $86,42 \pm 6,24$ & $1,62 \pm 0.16$ \\
\hline
\end{tabular}




\begin{tabular}{|c|c|c|c|c|c|c|c|c|}
\hline [D-Lys $\left.{ }^{3}\right]$ GHRP-6 & $7,31 \pm 0,46$ & $3,74 \pm 1,36$ & $4,70 \pm 0,19$ & $0,24 \pm 0,04$ & $8,78 \pm 1,78$ & $11,33 \pm 1,27$ & $82,74 \pm 6,30$ & $2,94 \pm 0.26$ \\
\hline pair-fed & $8,52 \pm 0,89$ & $11,12 \pm 2,69$ & $4,42 \pm 0,23$ & $0,64 \pm 0,25$ & $23,11 \pm 9,82$ & $8,30 \pm 0,55$ & $58,82 \pm 4,68++$ & $3,18 \pm 0.52$ \\
\hline
\end{tabular}

All values are expressed as mean \pm SEM ( $n=10$ per group, in pair-fed group, $n=5$ ). Significance (one-way ANOVA) is ${ }^{*} P<0.05$, ${ }^{* *} \mathrm{P}<0.01,{ }^{* * *} \mathrm{P}<0.001$ ([D-Lys $\left.{ }^{3}\right]$ GHRP-6 vs saline), ${ }^{+} \mathrm{P}<0,05,{ }^{++} \mathrm{P}<0,01,{ }^{+++} \mathrm{P}<0,001$ (pair-fed vs saline). 


\section{Table S1}

Metabolic parameters after seven-days SC administration of SPa in 17h fasted female mice

\begin{tabular}{|c|c|c|c|c|c|c|}
\hline Group/treatment & $\begin{array}{c}\text { Fat/body weight } \\
{[\%]}\end{array}$ & $\begin{array}{l}\text { Leptin } \\
{[\mathrm{ng} / \mathrm{ml}]}\end{array}$ & $\begin{array}{l}\text { Glucose } \\
{[\mathrm{mmol} / \mathrm{l}]}\end{array}$ & $\begin{array}{l}\text { Insulin } \\
\text { [ng/ml] }\end{array}$ & $\begin{array}{c}\text { Adiponectin } \\
{[\mu \mathrm{g} / \mathrm{ml}]}\end{array}$ & $\begin{array}{c}\text { Triglycerides } \\
{[\mathrm{mg} / \mathrm{dl}]}\end{array}$ \\
\hline \multicolumn{7}{|l|}{$\mathrm{A} / \mathrm{OVX} / \mathrm{St}$} \\
\hline Saline & $7,68 \pm 1,47$ & $11,81 \pm 5,46$ & $6,25 \pm 0,77$ & $\begin{array}{l}0,96 \pm \\
0,27\end{array}$ & $22,70 \pm 1,80$ & $75,69 \pm 5,84$ \\
\hline $\mathrm{SPa}$ & $6,37 \pm 0,53$ & $4,97 \pm 0,74$ & $5,44 \pm 0,55$ & $0,49 \pm$ & $29,52 \pm 1,13$ * & $67,62 \pm 4,67$ \\
\hline pair-fed & $7,68 \pm 0,52$ & $7,94 \pm 1,41$ & $5,46 \pm 0,61$ & $\begin{array}{c}0,27 \\
\pm 0,03 \\
+\end{array}$ & $32,10 \pm 2,13++$ & $73,15 \pm 7,40$ \\
\hline
\end{tabular}

\section{B/ OVX/HF}

$\begin{array}{ccccccc}\text { Saline } & 15,12 \pm 0,37 & 54,97 \pm 5,80 & 7,17 \pm 0,28 & 2,48 \pm & 22,77 \pm 0,91 & 83,82 \pm 4,14 \\ & & & 0,36 & & \\ \text { SPa } & 13,89 \pm 0,54 & 40,90 \pm 6,72 & 5,75 \pm 0,56 & 1,96 \pm & 23,49 \pm 0,53 & 64,45 \pm 2,87 \\ \text { pair-fed } & 13,72 \pm 0,56 & 59,35 \pm 7,71 & 7,12 \pm 0,45 & 1,58 \pm & 24,77 \pm 2,68 & 76,92 \pm 9,32 \\ & & & & 0,41 & \\ & & & & \end{array}$

\section{C/ OVX/St+E2}

Saline

$2,80 \pm 0,45$

$3,22 \pm 1,13$

$5,26 \pm 0,31$

$0,20 \pm$

$14,47 \pm 1,86$

$79,88 \pm 11,80$

$\mathrm{SPa}$

$2,52 \pm 0,41$

$1,75 \pm 0,66$

$5,20 \pm 0,32 \quad 0,21 \pm$

$19,06+3,67$

$75,76 \pm 5,40$

pair-fed

$3,64 \pm 0,40$

$1,97 \pm 0,38$

$4,90 \pm 0,29$

0,05

$0,68 \pm$

$11,22 \pm 2,09$

$56,67 \pm 2,48$

\section{D/ OVX/HF+E2}

Saline

$8,10 \pm 0,58$

$6,63 \pm 1,04$

$4,95 \pm 0,22$

0,46

$\pm 0,05$

$\mathrm{SPa}$

$7,97 \pm 0,83$

$6,10 \pm 2,38$

$5,43 \pm 0,35$

0,34

$\pm 0,06$

pair-fed

$9,11 \pm 1,50$

$5,62 \pm 0,31 \quad 1,19$ $\pm 0,27$

$8,14 \pm 0,72$

$86,42 \pm 6,24$

$8,59 \pm 2,78$

$68,33 \pm 7,61$

$12,80 \pm 1,83$

$56,44 \pm 2,23++$

All values are expressed as mean \pm SEM ( $n=10$ per group, in pair-fed group, $n=5$ ). Significance (one-way ANOVA) is ${ }^{*} \mathrm{P}<0.05$ (SPa vs saline), ${ }^{+} \mathrm{P}<0,05,{ }^{++} \mathrm{P}<0,01$, (pair-fed $v s$ saline) 
Maletínská et al

Manuscript to CME

\section{Highlights:}

- $\quad$ Estrogen deficient mice on high fat diet developed metabolic syndrome features.

- $\quad$ Ghrelin antagonist [D-Lys ${ }^{3}$ GHRP-6 improved metabolic parameters in these mice.

- $\quad$ Circulating FGF21 levels were markedly increased. 
Fig. 1

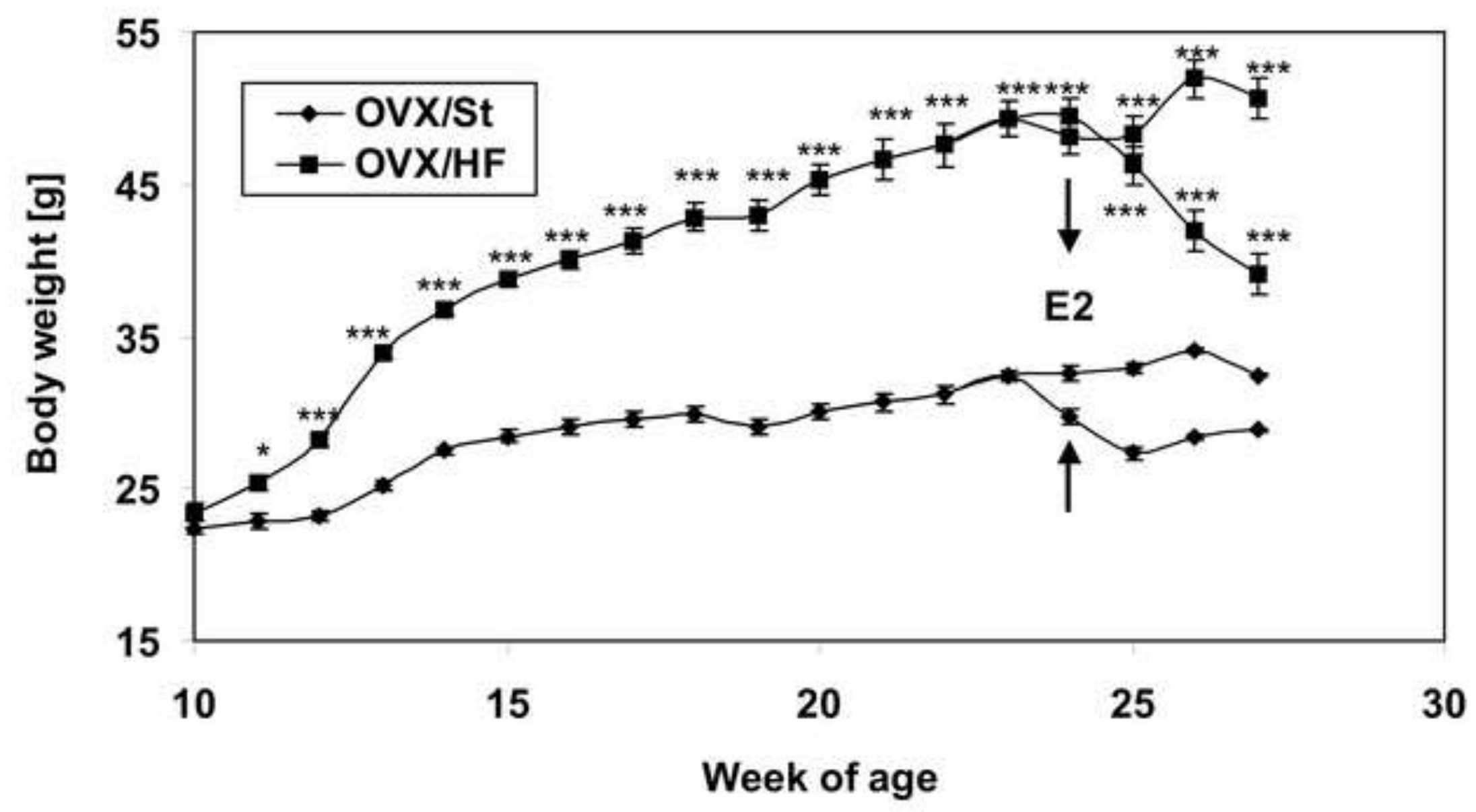




\section{ACCEPTED MANUSCRIPT}

Fig.2

A

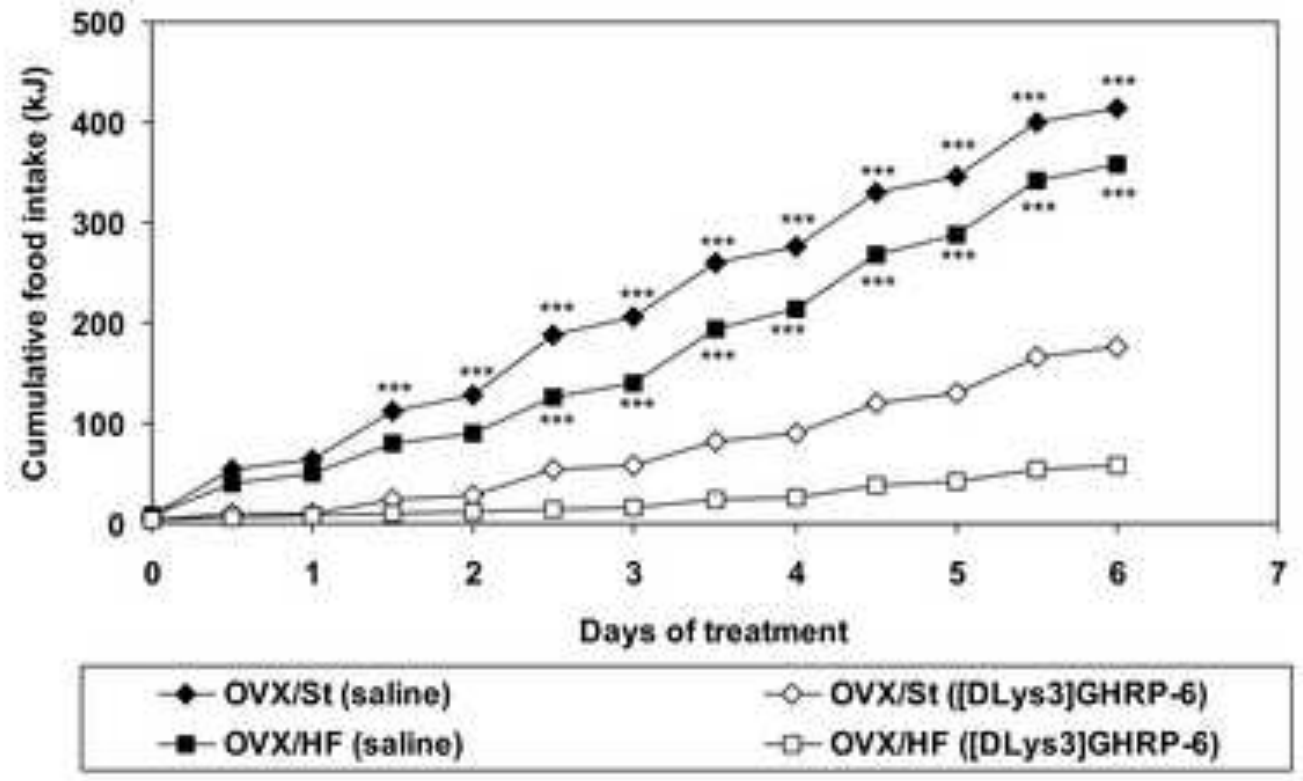

B

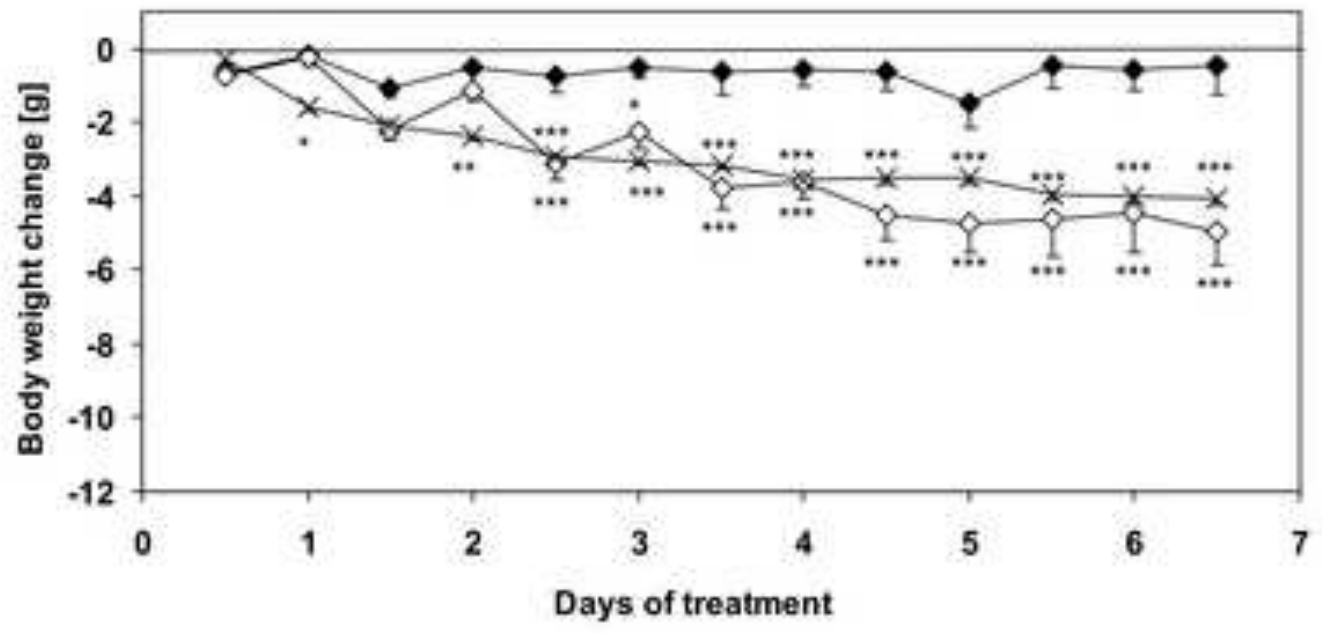

C






\section{ACCEPTED MANUSCRIPT}

\section{Fig.2 continued}

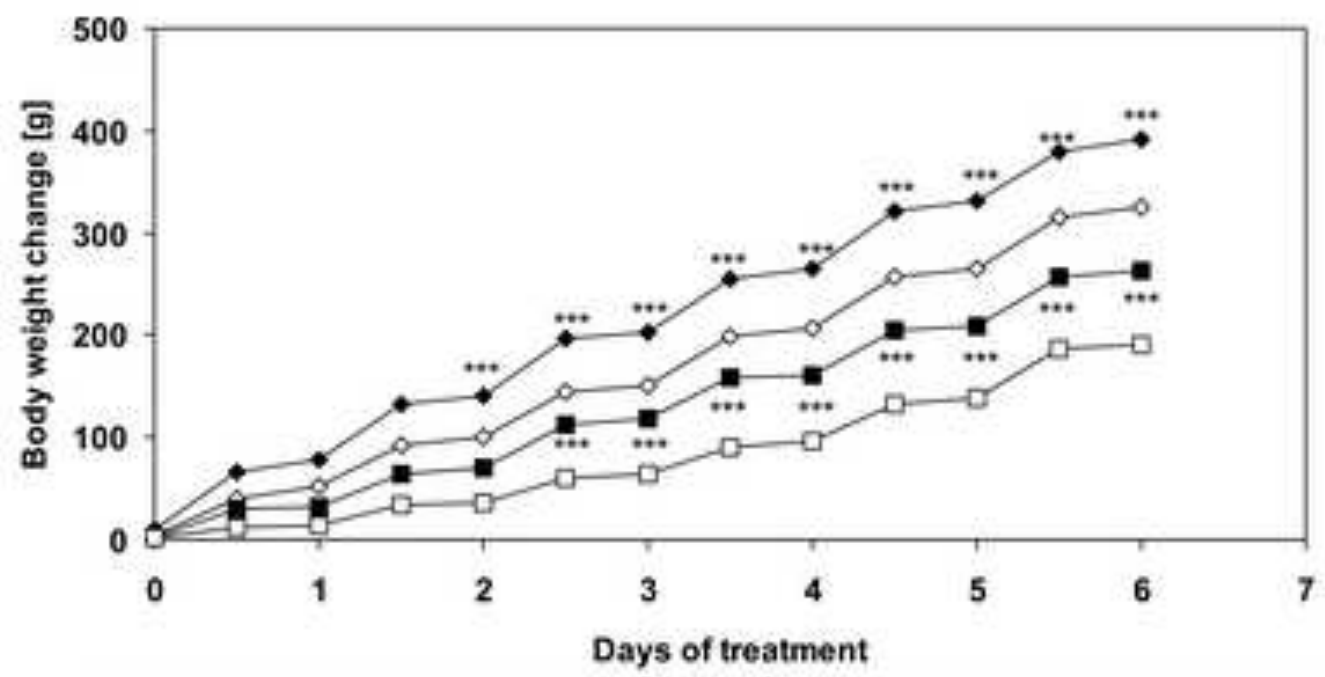

$\begin{array}{ll}\rightarrow \text { OVX/St+E2 (saline) } & -0 \text { OVX/St+E2 ([DLys3]GHRP-6) } \\ - \text { OVX/HF+E2 (saline) } & -\square-\text { OVX/HF+E2 ([DLys3]GHRP-6) }\end{array}$

E
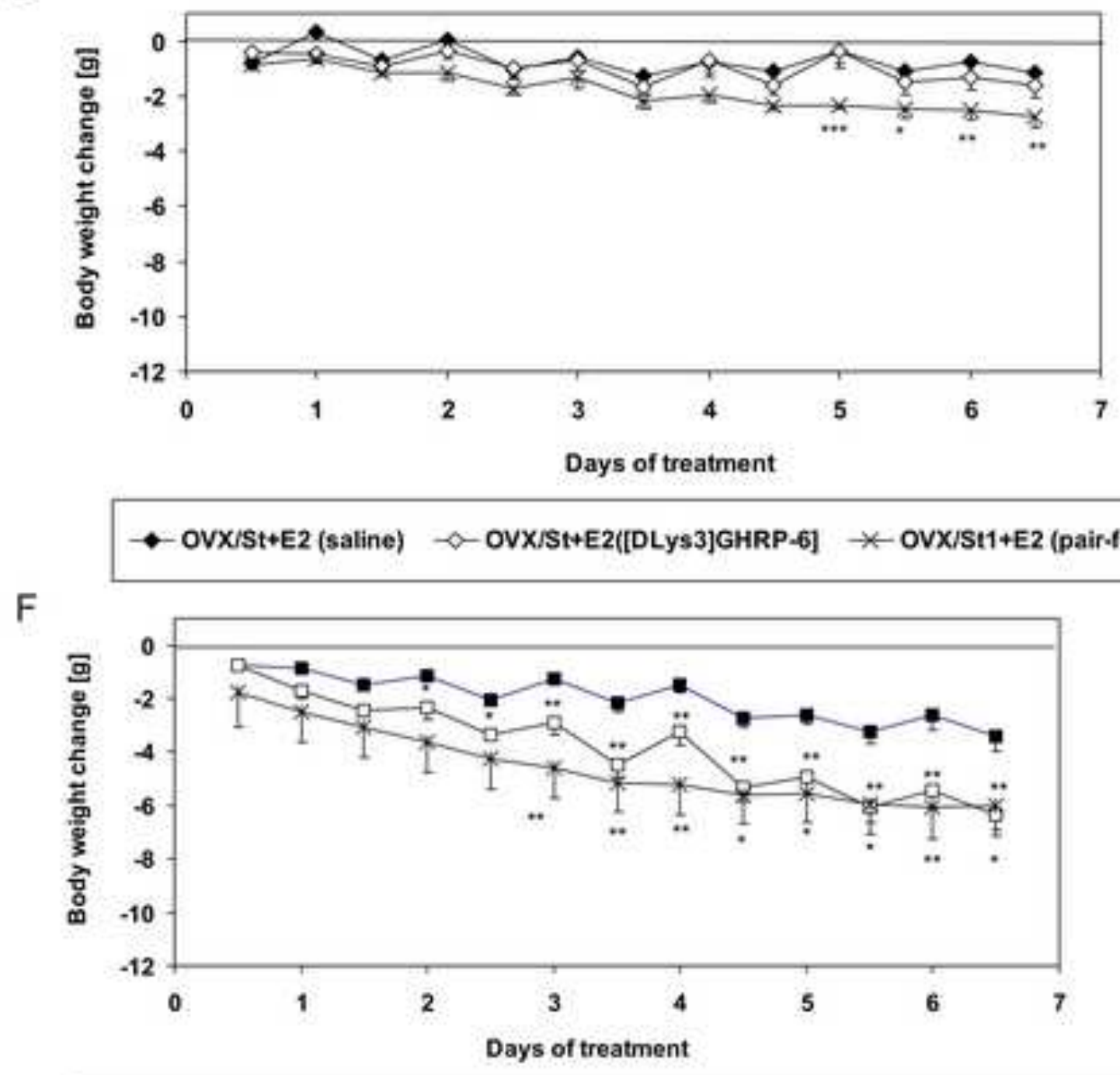
Fig. 3

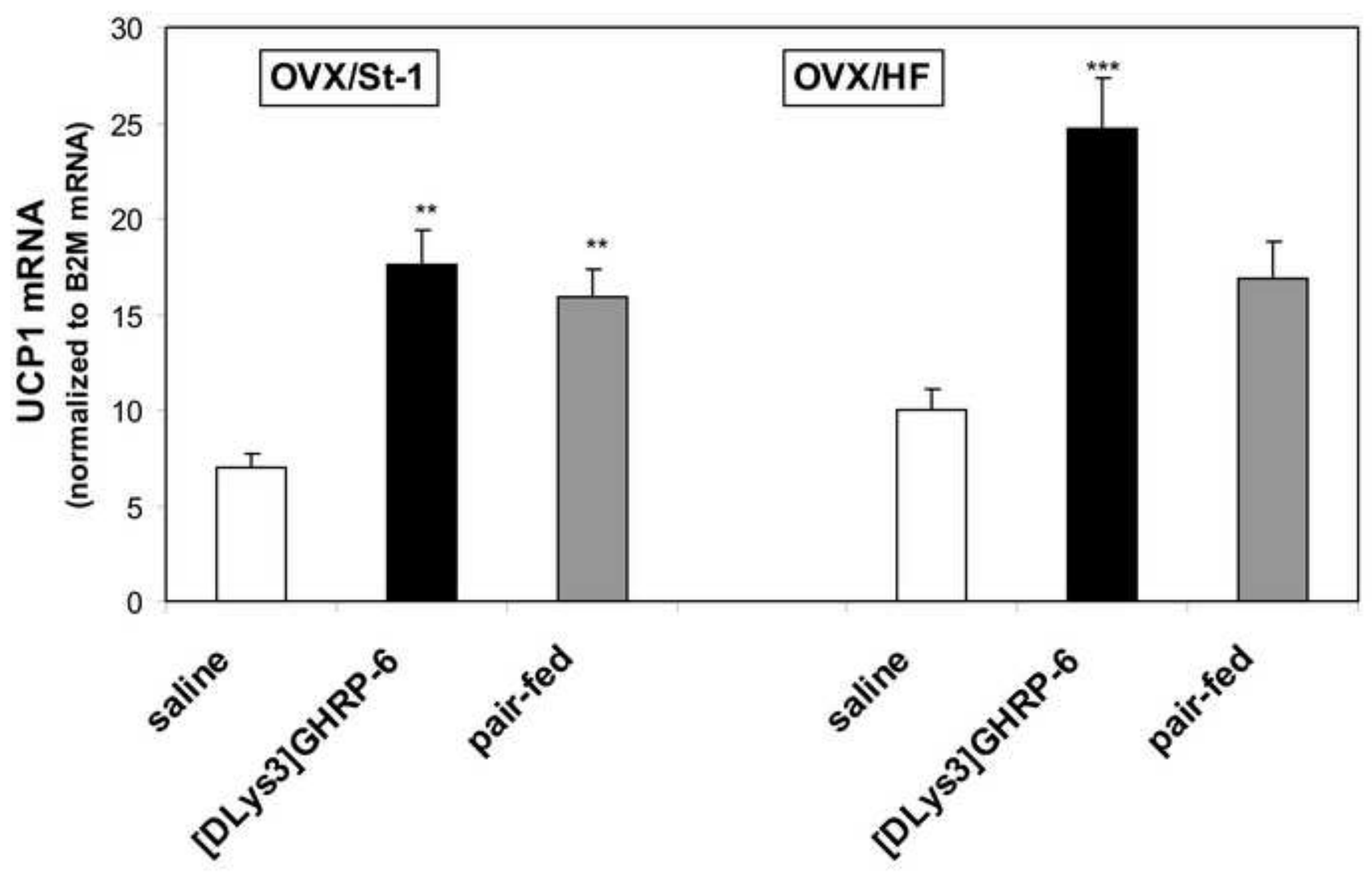


Fig.4

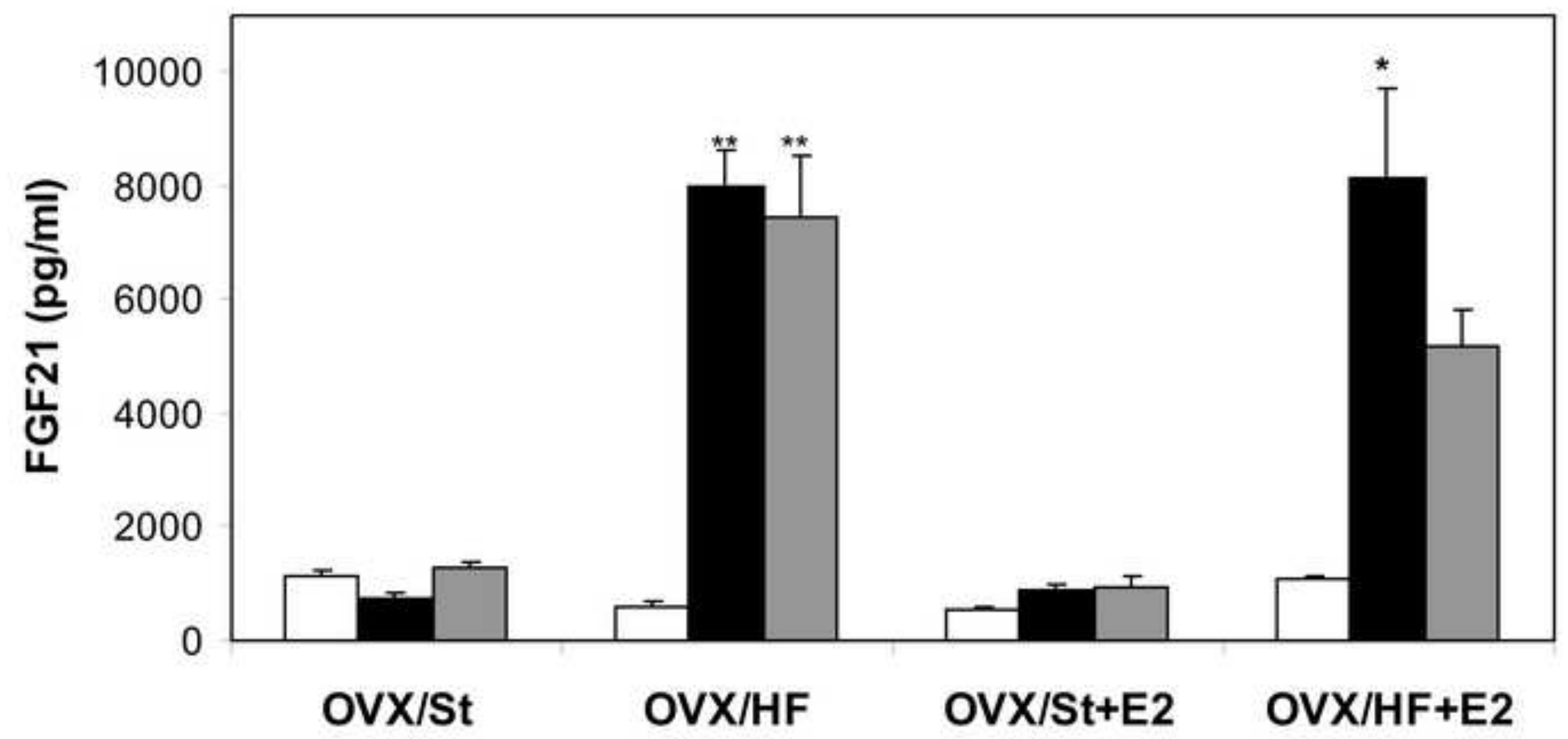

$\square$ saline $\square$ [DLys3]GHRP-6 $\square$ pair-fed 


\section{ACCEPTED MANUSCRIPT}

Fig. 5
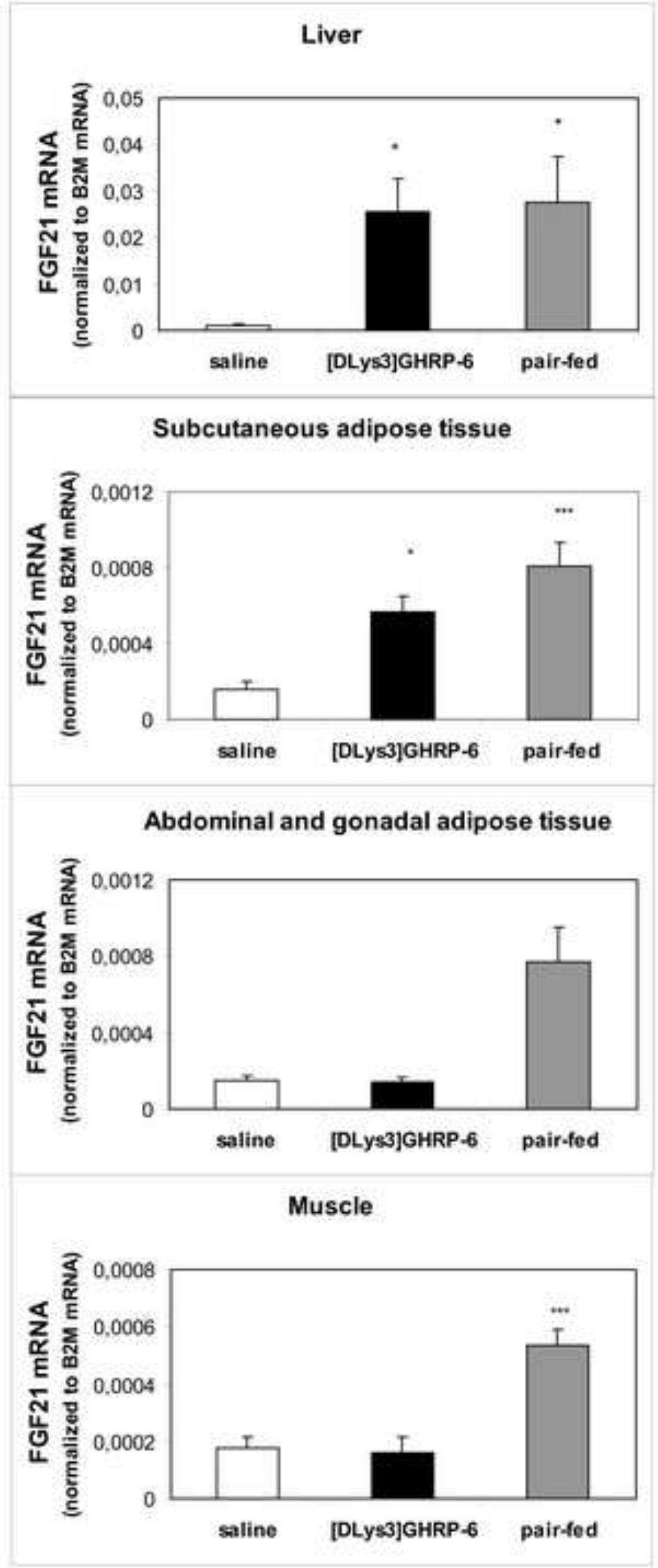
Fig.6

A

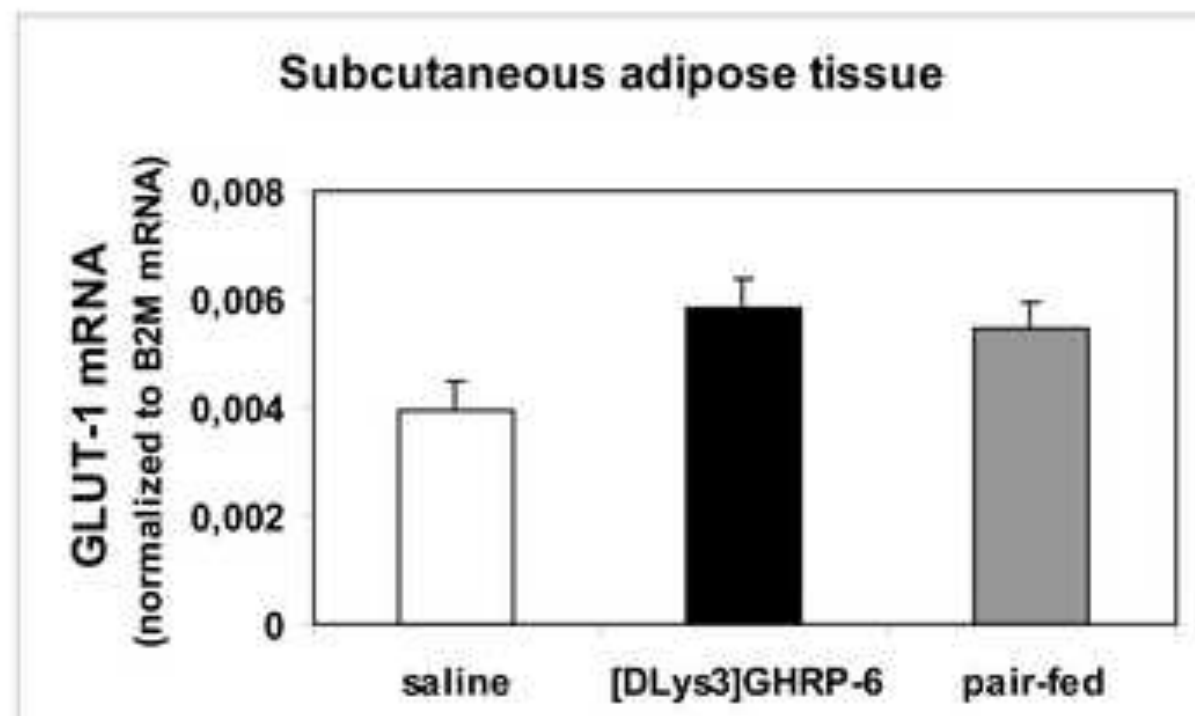

Abdominal and gonadal adipose tissue



B

Liver






\section{ACCEPTED MANUSCRIPT}

Fig. S1

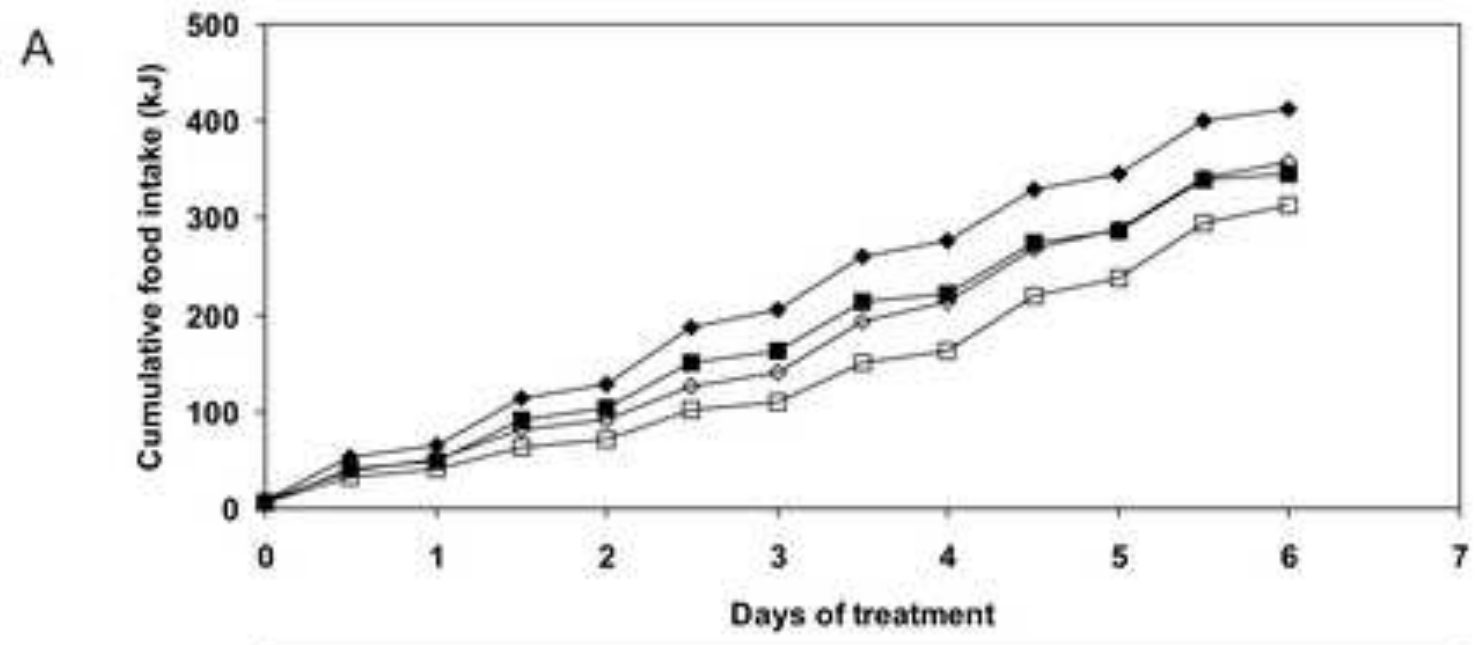

$\rightarrow$ ovX/St (saline) $\rightarrow$ oVX/St (SPa) $\rightarrow$ OVX/HF (saline) $\rightarrow$ OVX/HF (SPa)

B

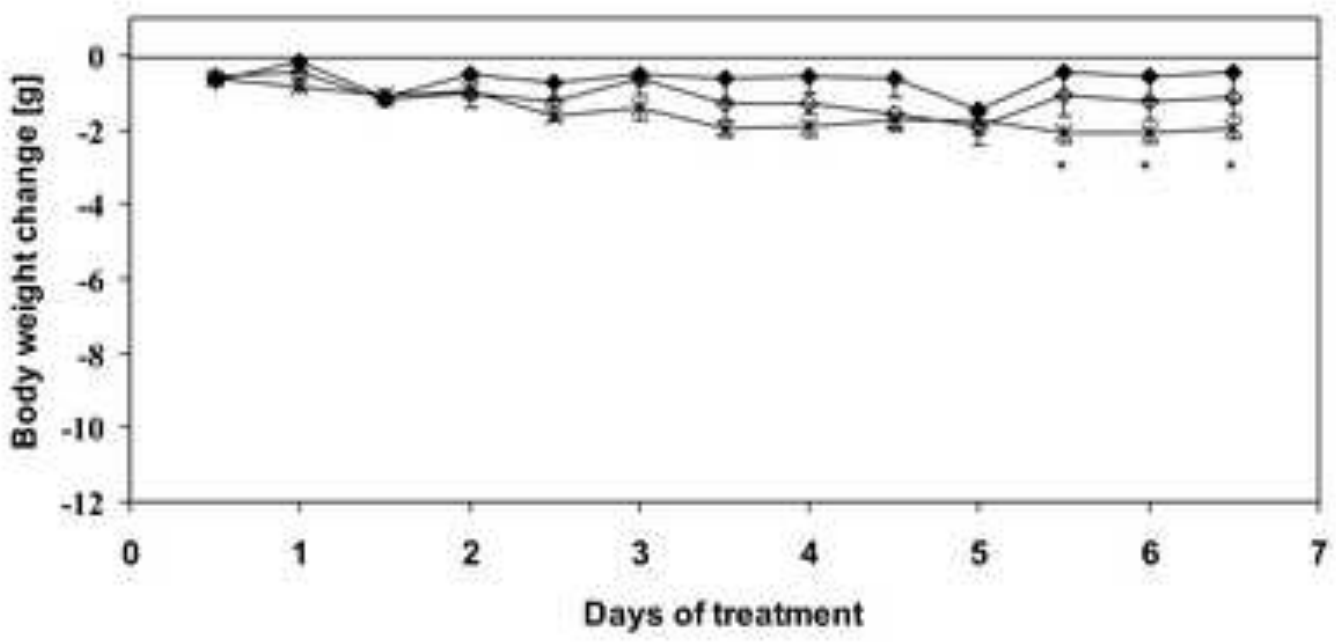

C

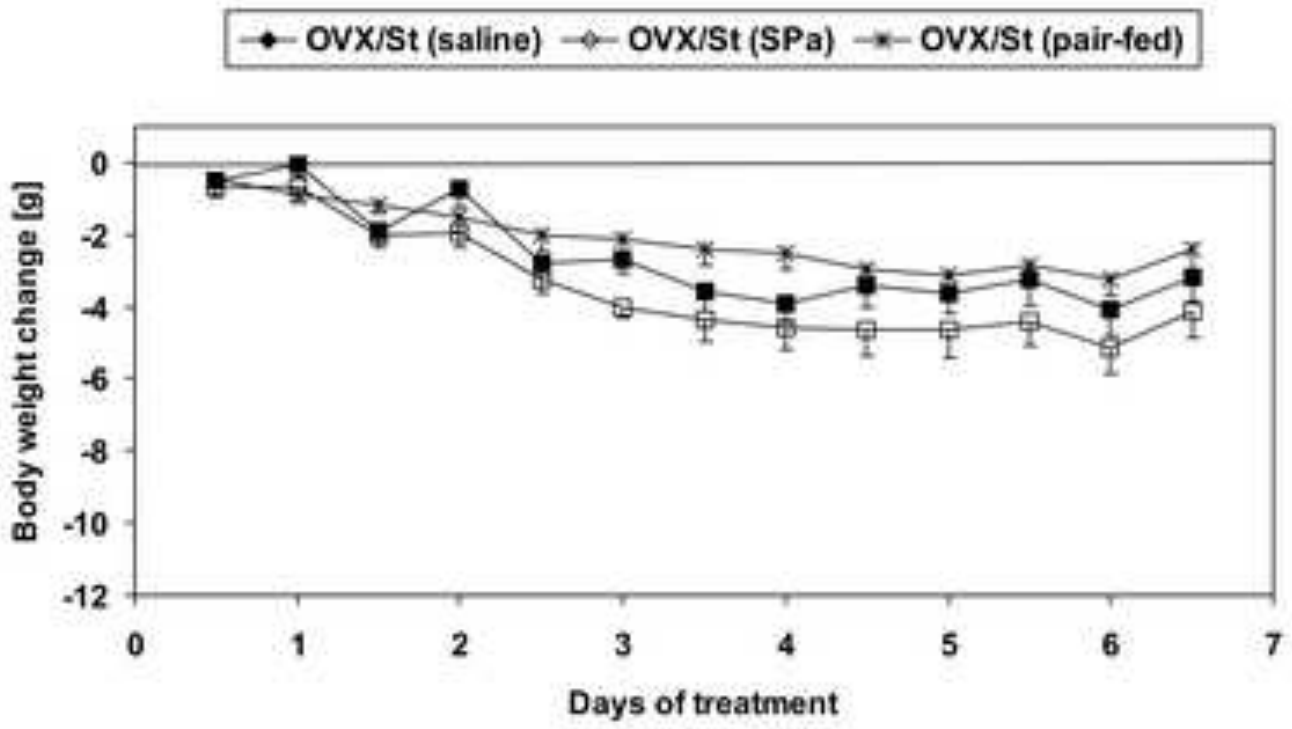

